\title{
Charting a course for erythropoietin in traumatic brain injury
}

\author{
Kenneth Maiese* \\ Cellular and Molecular Signaling, Newark, New Jersey 07101, USA
}

\begin{abstract}
Traumatic brain injury (TBI) is a severe public health problem that impacts more than four million individuals in the United States alone and is increasing in incidence on a global scale. Importantly, TBI can result in acute as well as chronic impairments for the nervous system leaving individuals with chronic disability and in instances of severe trauma, death becomes the ultimate outcome. In light of the significant negative health consequences of TBI, multiple therapeutic strategies are under investigation, but those focusing upon the cytokine and growth factor erythropoietin (EPO) have generated a great degree of enthusiasm. EPO can control cell death pathways tied to apoptosis and autophagy as well oversees processes that affect cellular longevity and aging. In vitro studies and experimental animal models of TBI have shown that EPO can restore axonal integrity, promote cellular proliferation, reduce brain edema, and preserve cellular energy homeostasis and mitochondrial function. Clinical studies for neurodegenerative disorders that involve loss of cognition or developmental brain injury support a positive role for EPO to prevent or reduce injury in the nervous system. However, recent clinical trials with EPO and TBI have not produced such clear conclusions. Further clinical studies are warranted to address the potential efficacy of EPO during TBI, the concerns with the onset, extent, and duration of EPO therapeutic strategies, and to focus upon the specific downstream pathways controlled by EPO such as protein kinase B (Akt), mechanistic target of rapamycin (mTOR), AMP activated protein kinase (AMPK), sirtuins, wingless pathways, and forkhead transcription factors for improved precision against the detrimental effects of TBI.
\end{abstract}

\section{Erythropoietin and traumatic brain injury: Translating experimental success into clinical efficacy}

In more than 30 million individuals throughout the world, both acute and chronic neurodegenerative disorders can result in significant disability as well as eventual death $[1,2]$. Chronic neurodegenerative diseases, such as Parkinson's disease (PD) [3,4], can affect approximately 4 percent of individuals over the age of sixty. In addition, the number of individuals with PD is expected to double by the year 2030. With disorders such as Alzheimer's disease (AD), this disease also can significantly impact the global population. For the sporadic form of $\mathrm{AD}$, approximately 10 percent of the global population over the age of sixty-five is affected $[3,5]$. Over the next two decades, it is estimated that the number of those suffering from $\mathrm{AD}$ will increase significantly to more than 30 million individuals [6-8].

For acute neurodegenerative injury, disorders such as stroke can impact almost 800,000 individuals every year with an annual cost of seventy-five billion United States (US) dollars [9]. Stroke results in multiple complications that can affect the economic welfare and daily function of individuals $[10,11]$. Cerebral ischemic disease is one of the five leading causes of death that also includes cardiac disease, cancer, chronic lower respiratory disease, and trauma [12]. As noted, trauma also significantly contributes to death and disability throughout the world and in particular, traumatic brain injury (TBI) can lead to devastating neurological disability [13,14]. TBI can result in impairments in memory and cognition, altered states of consciousness, psychiatric disturbances, and physical impairments that may be temporary or progress to permanent disability or death $[15,16]$. The combined rates for TBI related emergency department visits, hospitalizations, and deaths have significantly increased over the last ten years from 521 per 100,000 in 2001 to 824 per 100,000 in 2010 [17]. In young individuals of five to fourteen years of age, trauma as a result of being struck by an object accounted for almost forty percent of injuries. Falls accounted for an additional thirty-five percent of injuries. In older individuals of fifteen to forty-four years of age, assaults, falls, and motor vehicle accidents appear to account for the greatest proportion of TBI. In the age group that is sixty-five and older, falls are the predominant injury mechanism. Of significant concern is the fact that TBI can lead to both acute and chronic impairments for the nervous system [18-20]. Almost 50,000 individuals die every year as a result of TBI and approximately forty percent of all deaths from acute injuries in the United States are caused by TBI. Furthermore, more than 100,000 individuals suffer with chronic disability following TBI [21] and when severe trauma occurs, at least fifty percent of individuals die [22]. TBI continues as a severe public health problem affecting greater than four million individuals in the US alone with a continued increase in TBI rates [23].

Given the severe acute and long-standing negative health consequences that can occur following TBI, a number of interesting strategies are under investigation. These include targeting treatments with the mechanistic target of rapamycin (mTOR) [3,13], Wnt signaling pathways [24], nicotinamide [25-27], targets of oxidative stress [20,28], and sirtuins $[29,30]$. Yet, cytokines and growth factors offer interesting

Correspondence to: Kenneth Maiese, MD, Cellular and Molecular Signaling, USA; E-mail: wntin75@yahoo.com

Key words: Akt, Alzheimer's disease, apoptosis, autophagy, erythropoietin, forkhead, mTOR, Parkinson's disease, neurodegeneration, programmed cell death, sirtuins, traumatic brain injury, Wht

Received: March 15, 2016; Accepted: March 23, 2016; Published: March 26, 2016 
prospects for the treatment of TBI. Such agents are fostering a high level of enthusiasm for further investigation. In particular, the cytokine and growth factor erythropoietin (EPO) is under active study for the treatment of TBI [31].

At present, EPO and other erythropoiesis-stimulating agents (ESAs) have been approved by the US Food and Drug Administration for the treatment of anemia that results from chronic kidney failure, chemotherapy, human immunodeficiency virus, and to limit the number of blood transfusions for surgery $[32,33]$. EPO is produced and secreted throughout the body from sources that include the kidney peritubular interstitial cells, the brain, uterus, and liver [34-38]. EPO expression can be influenced by changes in oxygen tension and not by the concentration of red blood cells $[28,34,39]$. Expression of EPO also may be promoted by stimuli that are not related to hypoxia [40]. For example, agents that block inflammation in cerebral microglia have been recently shown to lead to the release of EPO [41] and xenon anesthesia in cardiac surgery can result in elevated EPO serum concentrations [42].

Located on chromosome 7, the EPO gene is present in a $5.4 \mathrm{~kb}$ region of the genomic DNA [43] and encodes for a polypeptide chain that has initially 193 amino acids. Subsequently, the EPO protein is cleaved of a 27 amino acid hydrophobic secretory leader at the aminoterminal to result in a 166 amino acid peptide [44]. Additional posttranslational processing occurs to result in a circulatory mature protein of 165 amino acids with a molecular weight of $30.4 \mathrm{kDa}$ with the removal of a carboxy-terminal arginine ${ }^{166}$ in the mature human and recombinant human EPO (rhEPO) [45,46]. Structural maintenance of EPO is dependent upon the oligosaccharide side chains [37,47]. EPO contains four glycosylated chains that include three $\mathrm{N}$-linked and one $O$-linked acidic oligosaccharide side chains [48]. The production and secretion of the mature EPO is dependent upon the $N$ - and $O$-linked chains for [47]. The carbohydrates are important for the clearance of EPO [49]. In addition, the oligosaccharides may offer protection from free radical activity [50], the carbohydrate chains stabilize the EPO protein [51], and the glycosylated chains prevent EPO degradation during free radical oxygen exposure [52].

With in-vitro and animal models, EPO can limit the detrimental effects of both apoptosis and autophagy under specific conditions $[53,54]$. In relation to apoptosis, EPO can block apoptosis during advanced glycation end-product (AGE) exposure in Schwann cells [55], cerebral ischemia [56,57], $\beta$-amyloid (A $\beta$ ) toxicity [58-61], and neuronal kainate-induced oxidative stress [62]. Furthermore, EPO has been shown to protect against apoptosis during retinal disease [63,64], cerebral microglia injury [41,61,64-68], oxygen deprivation [69-71], cerebral vascular injury $[66,72,73]$, and neurologic deterioration with diabetes mellitus [28,66,74-77].

During autophagy [78,79], EPO can block autophagy through the activation of mTOR [80-83]. EPO has been shown to modify the activity of autophagy and limit neonatal brain damage in the developing rodent during hyperoxia exposure and oxygen toxicity [84]. EPO also can protect against lipopolysaccharide-induced cell injury in other cell systems, such as renal mesangial cells, from autophagy [85]. In addition, EPO may rely upon autophagy pathways to block apoptosis. In neuronal cell line models, EPO can suppress apoptotic cell injury through the increased activity of AMP activated protein kinase (AMPK) and limited autophagy activity [86].

For models of TBI, application of recombinant human EPO and simvastatin during controlled cortical impact in a mouse model can restore axonal integrity and lead to new cellular proliferation [87]. In other animal studies, contusion volume from controlled cortical impact is reduced with EPO administration [88]. In a falling weight TBI model, EPO significantly decreases the number of apoptotic cells and brain edema [89]. During TBI, EPO also may control mitochondrial dysfunction [90] that has been previously shown with EPO in models of vascular, neuronal, microglial, adipocyte, and cardiomyocyte injury [62,68,69,72,91-97].

Progress in identifying the protective capacity of EPO with in vitro and animal models in the nervous system has given way to the initiation of clinical trials with EPO for TBI $[52,98]$. Overall, greater than sixty current or completed clinical trials are listed on the National Institutes of Health website ClinicalTrials.gov for nervous system disorders and EPO [31]. For disorders such as sporadic AD, increased expression of the EPO receptor in temporal cortical and hippocampal astrocytes has been observed and considered to be an early neuroprotective pathway [99]. In addition, high-dose erythropoietin treatment within forty-two hours after birth in preterm infants has been associated with reduced risk of brain injury documented through magnetic resonance imaging $[100,101]$. However, in regards to TBI, the results with EPO have not been so clear. EPO has been evaluated in trials that assess neurological recovery following TBI. In a randomized clinical trial of 200 patients, EPO was administered daily for three days (500 IU/kg per dose) and then weekly for two additional weeks. These results were also compared with patients receiving blood transfusion. At the completion of the trial, neither the administration of EPO or maintaining hemoglobin concentration above $10 \mathrm{~g} / \mathrm{dL}$ led to improvement in neurological outcome at six months [102]. In another larger clinical trial with close to six hundred patients that experienced brain injury, EPO (40,000 units administered subcutaneously) provided once per week for a maximum of three doses did not significantly affect six-month mortality, reduce severe neurological dysfunction, or increase the occurrence of deep venous thrombosis of the lower limbs [103].

Although cell culture and in vitro studies with EPO provide promising directives to translate the use of EPO into effective therapeutic strategies for disorders such as TBI, the current clinical observations with $\mathrm{EPO}$ and patients suffering form TBI suggest further investigations are warranted. First, although the current clinical studies with EPO and TBI did not reveal any toxicity with EPO, this may be secondary to the dosing selected for these trials. The onset, concentration, or duration of EPO administration chosen for these trials may not have been sufficient for clinical efficacy to be observed. Yet, construction of future studies that consider the dosing and exposure to EPO also must take into account that in some patients, such as in patients with diabetes mellitus and renal disease, EPO also can lead to toxic events such as a to a two-fold increase in stroke that is not attributed to any baseline characteristic or to blood pressure, hemoglobin, platelet count, or treatment dose of EPO [104]. Elevated EPO concentrations in patients with diabetes mellitus also may lead to proliferative diabetic retinopathy [105] that could be associated with excessive vascular growth. EPO may aggravate hypertension $[33,53,106]$ and result in sustained erythrocytosis that may lead to the activation of inflammatory pathways and blood-brain barrier dysfunction [107]. EPO, as a growth factor and proliferative entity, also can promote tumor growth and lead to the progression of existing tumors [108-111].

Second, another avenue of investigation for EPO and TBI could involve targeting more specific pathways controlled by EPO such as protein kinase $\mathrm{B}(\mathrm{Akt})$ that can foster a number of protective 
pathways in the nervous system with EPO [112-115]. Other pathways that can modulate the protective effects of EPO include mTOR $[68,80,82,83]$, AMPK $[41,96]$, sirtuins $[72,116,117]$, wingless pathways $[68,72,91,118,119]$, and forkhead transcription factors $[57,113,120]$. Focusing upon the specific exposure and concentration of EPO as well as the downstream signaling pathways of this entity may provide further precision in targeting the detrimental cellular events that ensue following TBI and concurrently limit the potential toxic effects that can develop during EPO administration.

\section{Acknowledgments}

This research was supported by the following grants to Kenneth Maiese: American Diabetes Association, American Heart Association, NIH NIEHS, NIH NIA, NIH NINDS, and NIH ARRA.

\section{References}

1. Maiese K (2015) FoxO proteins in the nervous system. Anal Cell Pathol (Amst) 2015: 569392. [Crossref]

2. Poulose N, Raju R (2015) Sirtuin regulation in aging and injury. Biochim Biophys Acta 1852: 2442-2455. [Crossref]

3. Maiese K (2015) Targeting molecules to medicine with mTOR, autophagy, and neurodegenerative disorders. Br J Clin Pharmacol [Crossref]

4. Zhang H, Duan C, Yang H (2015) Defective autophagy in Parkinson's disease: lessons from genetics. Mol Neurobiol 51: 89-104. [Crossref]

5. Wang W, Mandel J, Bouaziz J, Commenges D, Nabirotchkine S, et al. (2015) A MultiMarker Genetic Association Test Based on the Rasch Model Applied to Alzheimer's Disease. PLoS One 10: $\mathrm{e} 0138223$. [Crossref]

6. Maiese K (2014) Taking aim at Alzheimer's disease through the mammalian target of rapamycin. Ann Med 46: 587-596. [Crossref]

7. Maiese K (2014) Driving neural regeneration through the mammalian target of rapamycin. Neural Regen Res 9: 1413-1417. [Crossref]

8. Schluesener JK, Zhu X, Schluesener HJ, Wang GW, Ao P (2014) Key network approach reveals new insight into Alzheimer's disease. IET Syst Biol 8: 169-175. [Crossref]

9. Maiese K (2014) Cutting through the complexities of mTOR for the treatment of stroke. Curr Neurovasc Res 11: 177-186. [Crossref]

10. Chen W, Sun Y, Liu K, Sun X (2014) Autophagy: a double-edged sword for neuronal survival after cerebral ischemia. Neural Regen Res 9: 1210-1216. [Crossref]

11. Maiese K (2015) mTOR: Driving apoptosis and autophagy for neurocardiac complications of diabetes mellitus. World J Diabetes 6: 217-224. [Crossref]

12. Minino AM, Murphy SL (2012) Death in the United States, 2010. NCHS data brief 99: 1-8. [Crossref]

13. Berry M, Ahmed Z, Morgan-Warren P, Fulton D, Logan A (2016) Prospects for mTORmediated functional repair after central nervous system trauma. Neurobiol Dis 85: 99110. [Crossref]

14. Chong ZZ, Li F, Maiese K (2005) Oxidative stress in the brain: novel cellular targets that govern survival during neurodegenerative disease. Prog Neurobiol 75: 207-246. [Crossref]

15. Harish G, Mahadevan A, Pruthi N, Sreenivasamurthy SK, et al. (2015) Characterization of traumatic brain injury in human brains reveals distinct cellular and molecular changes in contusion and pericontusion. J Neurochem 134: 156-172. [Crossref]

16. Hellewell SC, Morganti-Kossmann MC (2012) Guilty molecules, guilty minds? The conflicting roles of the innate immune response to traumatic brain injury. Mediators Inflamm 2012: 356494. [Crossref]

17. Centers for Disease Control and Prevention. Traumatic Brain Injury and Concussion. http://wwwcdcgov/traumaticbraininjury/data/.(Accessed March 2, 2016).

18. Lee JH, Wei L, Gu X, Wei Z, Dix TA, et al. (2014) Therapeutic effects of pharmacologically induced hypothermia against traumatic brain injury in mice. $J$ Neurotrauma 31: 1417-1430. [Crossref]

19. Maiese K (2011) Coma and impaired consciousness. The Merck Manual. 19th Professional Edition.
20. Wang JW, Wang HD, Cong ZX, Zhou XM, Xu JG, et al. (2014) Puerarin ameliorates oxidative stress in a rodent model of traumatic brain injury. J Surg Res 186: 328-337. [Crossref]

21. Kumar PR, Essa MM, Al-Adawi S, Dradekh G, Memon MA3, et al. (2014) Omega-3 Fatty acids could alleviate the risks of traumatic brain injury - a mini review. $J$ Tradit Complement Med 4: 89-92. [Crossref]

22. Corrigan JD, Cuthbert JP, Harrison-Felix C, Whiteneck GG, Bell JM, et al. (2014) US population estimates of health and social outcomes 5 years after rehabilitation for traumatic brain injury. J Head Trauma Rehabil 29: E1-9. [Crossref]

23. Coronado VG, McGuire LC, Sarmiento K, Bell J, Lionbarger MR, et al. (2012) Trends in Traumatic Brain Injury in the U.S. and the public health response: 1995-2009. $J$ Safety Res 43: 299-307. [Crossref]

24. Maiese K (2014) WISP1: Clinical insights for a proliferative and restorative member of the CCN family. Curr Neurovasc Res 11: 378-389. [Crossref]

25. Maiese K, Chong ZZ, Hou J, Shang YC (2009) The vitamin nicotinamide: translating nutrition into clinical care. Molecules 14: 3446-3485. [Crossref]

26. Peterson TC, Hoane MR, McConomy KS, Farin FM, Bammler TK, et al. (2015) A Combination Therapy of Nicotinamide and Progesterone Improves Functional Recovery following Traumatic Brain Injury. J Neurotrauma 32: 765-779. [Crossref]

27. Vonder Haar C, Maass WR, Jacobs EA, Hoane MR (2014) Deficits in discrimination after experimental frontal brain injury are mediated by motivation and can be improved by nicotinamide administration. J Neurotrauma 31: 1711-1720. [Crossref]

28. Maiese K (2015) Novel applications of trophic factors, Wnt and WISP for neuronal repair and regeneration in metabolic disease. Neural Regen Res 10: 518-528. [Crossref]

29. Maiese K (2015) SIRT1 and stem cells: In the forefront with cardiovascular disease, neurodegeneration and cancer. World J Stem Cells 7: 235-242. [Crossref]

30. Zhao Y, Luo P, Guo Q, Li S, Zhang L, et al. (2012) Interactions between SIRT1 and MAPK/ERK regulate neuronal apoptosis induced by traumatic brain injury in vitro and in vivo. Exp Neurol 237: 489-498. [Crossref]

31. Maiese K (2016) Regeneration in the nervous system with erythropoietin. Front Biosci (Landmark Ed) 21: 561-596. [Crossref]

32. Li F, Chong ZZ, Maiese K (2004) Erythropoietin on a tightrope: balancing neuronal and vascular protection between intrinsic and extrinsic pathways. Neurosignals 13 265-289. [Crossref]

33. Palazzuoli A, Ruocco G, Pellegrini M, De Gori C, Del Castillo G, et al. (2014) The role of erythropoietin stimulating agents in anemic patients with heart failure: solved and unresolved questions. Ther Clin Risk Manag 10: 641-650. [Crossref]

34. Caprara C, Grimm C (2012) From oxygen to erythropoietin: relevance of hypoxia fo retinal development, health and disease. Prog Retin Eye Res 31: 89-119. [Crossref]

35. Chong ZZ, Kang JQ, Maiese K (2002) Angiogenesis and plasticity: role of erythropoietin in vascular systems. J Hematother Stem Cell Res 11: 863-871. [Crossref]

36. Kato S, Aoyama M, Kakita H, Hida H, Kato I, et al. (2011) Endogenous erythropoietin from astrocyte protects the oligodendrocyte precursor cell against hypoxic and reoxygenation injury. $J$ Neurosci Res 89: 1566-1574. [Crossref]

37. Maiese K, Li F, Chong ZZ (2004) Erythropoietin in the brain: can the promise to protect be fulfilled? Trends Pharmacol Sci 25: 577-583. [Crossref]

38. Moore EM, Bellomo R, Nichol AD (2011) Erythropoietin as a novel brain and kidney protective agent. Anaesth Intensive Care 39: 356-372. [Crossref]

39. Maiese K (2008) Triple play: promoting neurovascular longevity with nicotinamide, WNT, and erythropoietin in diabetes mellitus. Biomed Pharmacother 62: 218-232. [Crossref]

40. Maiese K (2015) Erythropoietin and diabetes mellitus. World J Diabetes 6: 1259-1273. [Crossref]

41. Tsai CF, Kuo YH, Yeh WL, Wu CY, et al. (2015) Regulatory effects of caffeic acid phenethyl ester on neuroinflammation in microglial cells. Int J Mol Sci 16: 5572-5589. [Crossref]

42. Stoppe C, Ney J, Brenke M, Goetzenich A, et al. (2016) Sub-anesthetic Xenon Increases Erythropoietin Levels in Humans: A Randomized Controlled Trial. Sports Med. [Crossref]

43. Maiese K, Li F, Chong ZZ (2005) New avenues of exploration for erythropoietin JAMA 293: 90-95. [Crossref]

44. Imai N, Kawamura A, Higuchi M, Oh-eda M, Orita T, et al. (1990) Physicochemical 
and biological comparison of recombinant human erythropoietin with human urinary erythropoietin. J Biochem 107: 352-359. [Crossref]

45. Kucuk B, Cevik Y, Acar U, Sobaci G (2015) Therapeutic Potential of Erythropoietin in Retinal and Optic Nerve Diseases. CNS Neurol Disord Drug Targets 14: 1225-1234. [Crossref]

46. Maiese K, Chong ZZ, Li F, Shang YC (2008) Erythropoietin: elucidating new cellular targets that broaden therapeutic strategies. Prog Neurobiol 85: 194-213. [Crossref]

47. Krantz SB (1991) Erythropoietin. Blood 77: 419-434. [Crossref]

48. Maiese K, Chong ZZ, Hou J, Shang YC (2008) Erythropoietin and oxidative stress. Curr Neurovasc Res 5: 125-142. [Crossref]

49. Tsuda E, Kawanishi G, Ueda M, Masuda S, Sasaki R (1990) The role of carbohydrate in recombinant human erythropoietin. Eur J Biochem 188: 405-411. [Crossref]

50. Uchida E, Morimoto K, Kawasaki N, Izaki Y, Abdu Said A, et al. (1997) Effect of active oxygen radicals on protein and carbohydrate moieties of recombinant human erythropoietin. Free Radic Res 27: 311-323. [Crossref]

51. Toyoda T, Itai T, Arakawa T, Aoki KH, Yamaguchi H (2000) Stabilization of human recombinant erythropoietin through interactions with the highly branched $\mathrm{N}$-glycans. $J$ Biochem 128: 731-737. [Crossref]

52. Maiese K, Chong ZZ, Shang YC, Wang S (2012) Erythropoietin: new directions for the nervous system. Int J Mol Sci 13: 11102-11129. [Crossref]

53. Maiese K, Chong ZZ, Hou J, Shang YC (2010) Oxidative stress: Biomarkers and novel therapeutic pathways. Exp Gerontol 45: 217-234. [Crossref]

54. Nguyen AQ, Cherry BH, Scott GF, Ryou MG, Mallet RT (2014) Erythropoietin: powerful protection of ischemic and post-ischemic brain. Exp Biol Med (Maywood) 239: 1461-1475. [Crossref]

55. Yu T, Li L, Chen T, Liu Z, Liu H, et al. (2015) Erythropoietin attenuates advanced glycation endproducts-induced toxicity of Schwann cells in vitro. Neurochem Res 40: 698-712. [Crossref]

56. Ishii T, Asai T, Fukuta T, Oyama D, Yasuda N, et al. (2012) A single injection of liposomal asialo-erythropoietin improves motor function deficit caused by cerebral ischemia/reperfusion. Int J Pharm 439: 269-274. [Crossref]

57. Zhao H, Wang R, Wu X, Liang J, Qi Z, et al. (2015) Erythropoietin delivered via intraarterial infusion reduces endoplasmic reticulum stress in brain microvessels of rats following cerebral ischemia and reperfusion. J Neuroimmune Pharmacol 10: 153-161. [Crossref]

58. Chong ZZ, Li F, Maiese K (2005) Erythropoietin requires NF-kappaB and its nuclear translocation to prevent early and late apoptotic neuronal injury during beta-amyloid toxicity. Curr Neurovasc Res 2: 387-399. [Crossref]

59. Esmaeili Tazangi P, Moosavi SM, Shabani M, Haghani M (2015) Erythropoietin improves synaptic plasticity and memory deficits by decrease of the neurotransmitter release probability in the rat model of Alzheimer's disease. Pharmacol Biochem Behav 130: 15-21. [Crossref]

60. Li YP, Yang GJ, Jin L, Yang HM, Chen J, et al. (2015) Erythropoietin attenuates Alzheimer-like memory impairments and pathological changes induced by amyloid $\beta 42$ in mice. Brain Res 1618: 159-167. [Crossref]

61. Shang YC, Chong ZZ, Wang S, Maiese K (2012) Prevention of $\beta$-amyloid degeneration of microglia by erythropoietin depends on Wnt, the PI 3-K/mTOR pathway, Bad, and Bcl-xL. Aging (Albany NY) 4: 187-201. [Crossref]

62. Costa DC, Alva N, Trigueros L, Gamez A, Carbonell T, et al. (2013) Intermittent hypobaric hypoxia induces neuroprotection in kainate-induced oxidative stress in rats. J Mol Neurosci 50: 402-410. [Crossref]

63. Caprara C, Britschgi C, Samardzija M, Grimm C (2014) The erythropoietin receptor is not required for the development, function, and aging of rods and cells in the retinal periphery. Mol Vis 20: 307-324. [Crossref]

64. Shen W, Chung SH, Irhimeh MR, Li S, Lee SR, et al. (2014) Systemic administration of erythropoietin inhibits retinopathy in RCS rats. PLoS One 9: e104759. [Crossref]

65. Bond WS, Rex TS (2014) Evidence That Erythropoietin Modulates Neuroinflammation through Differential Action on Neurons, Astrocytes, and Microglia. Front Immunol 5: 523. [Crossref]

66. Busch S, Kannt A, Kolibabka M, Schlotterer A, Wang Q, et al. (2014) Systemic treatment with erythropoietin protects the neurovascular unit in a rat model of retinal neurodegeneration. PLoS One 9: e102013. [Crossref]
67. Li F, Chong ZZ, Maiese K (2006) Microglial integrity is maintained by erythropoietin through integration of Akt and its substrates of glycogen synthase kinase-3beta, betacatenin, and nuclear factor-kappaB. Curr Neurovasc Res 3: 187-201. [Crossref]

68. Shang YC, Chong ZZ, Wang S, Maiese K (2011) Erythropoietin and Wnt1 govern pathways of mTOR, Apaf-, and XIAP in inflammatory microglia. Curr Neurovasc Res 8: 270-285. [Crossref]

69. Chong ZZ, Kang JQ, Maiese K (2002) Erythropoietin is a novel vascular protectant through activation of Aktl and mitochondrial modulation of cysteine proteases. Circulation 106: 2973-2979. [Crossref]

70. Hralová M, Angerová Y, Gueye T, Bortelová J, Svestková O, et al. (2013) Long-term results of enriched environment and erythropoietin after hypobaric hypoxia in rats. Physiol Res 62: 463-470. [Crossref]

71. Hussein MH, Daoud GA, Kakita H, Kato S, Goto T, et al. (2010) High cerebrospinal fluid antioxidants and interleukin 8 are protective of hypoxic brain damage in newborns. Free Radic Res 44: 422-429. [Crossref]

72. Hou J, Wang S, Shang YC, Chong ZZ, Maiese K (2011) Erythropoietin employs cell longevity pathways of SIRT1 to foster endothelial vascular integrity during oxidant stress. Curr Neurovasc Res 8: 220-235. [Crossref]

73. Oba T, Yasukawa H, Nagata T, Kyogoku S, Minami T, et al. (2015) Renal NerveMediated Erythropoietin Release Confers Cardioprotection During Remote Ischemic Preconditioning. Circ J 79: 1557-1567. [Crossref]

74. Gradinaru D, Margina D, Ilie M, Borsa C, Ionescu C, et al. (2015) Correlation between erythropoietin serum levels and erythrocyte susceptibility to lipid peroxidation in elderly with type 2 diabetes. Acta physiol Hung 102: 400-408. [Crossref]

75. Hamed S, Bennett CL, Demiot C, Ullmann Y, Teot L, et al. (2014) Erythropoietin, a novel repurposed drug: an innovative treatment for wound healing in patients with diabetes mellitus. Wound Repair Regen 22: 23-33. [Crossref]

76. Maiese K, Chong ZZ, Shang YC, Wang S (2013) Novel directions for diabetes mellitus drug discovery. Expert Opin Drug Discov 8: 35-48. [Crossref]

77. Wang L, Di L, Noguchi CT (2014) Erythropoietin, a novel versatile player regulating energy metabolism beyond the erythroid system. Int J Biol Sci 10: 921-939. [Crossref]

78. Klionsky DJ, Abdelmohsen K, Abe A, Abedin MJ, Abeliovich H, et al. (2016) Guidelines for the use and interpretation of assays for monitoring autophagy (3rd edition). Autophagy 12: 1-222. [Crossref]

79. Maiese K, Chong ZZ, Shang YC, Wang S (2012) Targeting disease through nove pathways of apoptosis and autophagy. Expert Opin Ther Targets 16: 1203-1214. [Crossref]

80. Chong ZZ, Shang YC, Wang S, Maiese K (2012) PRAS40 is an integral regulatory component of erythropoietin mTOR signaling and cytoprotection. PLoS One 7: e45456. [Crossref]

81. Maiese K (2016) Molecules to Medicine with mTOR: Translating Critical Pathways into Novel Therapeutic Strategies. Elsevier and Academic Press, USA [Crossref]

82. Marfia G, Madaschi L, Marra F, Menarini M, Bottai D, et al. (2011) Adult neural precursors isolated from post mortem brain yield mostly neurons: an erythropoietindependent process. Neurobiol Dis 43: 86-98. [Crossref]

83. Ryou MG, Choudhury GR, Li W, Winters A, Yuan F, et al. (2015) Methylene blueinduced neuronal protective mechanism against hypoxia-reoxygenation stress Neuroscience 301: 193-203. [Crossref]

84. Bendix I, Schulze C, Haefen C, Gellhaus A, Endesfelder S, et al. (2012) Erythropoietin modulates autophagy signaling in the developing rat brain in an in vivo model of oxygen-toxicity. Int J Mol Sci 13: 12939-12951. [Crossref]

85. Bi L, Hou R, Yang D, Li S, Zhao D (2015) Erythropoietin protects lipopolysaccharideinduced renal mesangial cells from autophagy. Exp Ther Med 9: 559-562. [Crossref]

86. Jang W, Kim HJ, Li H (2015) The Neuroprotective Effect of Erythropoietin on Rotenone-Induced Neurotoxicity in SH-SY5Y Cells Through the Induction of Autophagy. Mol Neurobiol . [Crossref]

87. Chauhan NB, Gatto R (2010) Synergistic benefits of erythropoietin and simvastatin after traumatic brain injury. Brain Res 1360: 177-192. [Crossref]

88. Cherian L, Goodman JC, Robertson C (2007) Neuroprotection with erythropoietin administration following controlled cortical impact injury in rats. J Pharmacol Exp Ther 322: 789-794. [Crossref]

89. Xu F, Yu ZY, Ding L, Zheng SY (2012) Experimental studies of erythropoietin protection following traumatic brain injury in rats. Exp Ther Med 4: 977-982. [Crossref] 
90. Millet A, Bouzat P, Trouve-Buisson T, Batandier C, Pernet-Gallay K, et al. (2016) Erythropoietin and Its Derivates Modulate Mitochondrial Dysfunction after Diffuse Traumatic Brain Injury. $J$ Neurotrauma [Crossref]

91. Chong ZZ, Hou J, Shang YC, Wang S, Maiese K (2011) EPO relies upon novel signaling

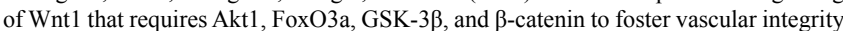
during experimental diabetes. Curr Neurovasc Res 8: 103-120. [Crossref]

92. Chong ZZ, Kang JQ, Maiese K (2003) Apaf-, Bcl-xL, cytochrome c, and caspase-9 form the critical elements for cerebral vascular protection by erythropoietin. J Cereb Blood Flow Metab 23: 320-330. [Crossref]

93. Chong ZZ, Kang JQ, Maiese K (2003) Erythropoietin fosters both intrinsic and extrinsic neuronal protection through modulation of microglia, Akt, Bad, and caspasemediated pathways. Br J Pharmacol 138: 1107-1118. [Crossref]

94. Chong ZZ, Lin SH, Kang JQ, Maiese K (2003) Erythropoietin prevents early and late neuronal demise through modulation of Akt1 and induction of caspase, 3, and $8 . J$ Neurosci Res 71: 659-669. [Crossref]

95. Parvin A, Pranap R, Shalini U, Devendran A, Baker JE, et al. (2014) Erythropoietin protects cardiomyocytes from cell death during hypoxia/reperfusion injury through activation of survival signaling pathways. PLoS One 9: e107453. [Crossref]

96. Wang L, Di L, Noguchi CT3 (2014) AMPK is involved in mediation of erythropoietin influence on metabolic activity and reactive oxygen species production in white adipocytes. Int J Biochem Cell Biol 54: 1-9. [Crossref]

97. Zhang X, Dong S, Qin Y, Bian X (2015) Protective effect of erythropoietin against myocardial injury in rats with sepsis and its underlying mechanisms. Mol Med Rep 11: 3317-3329. [Crossref]

98. Ponce LL, Navarro JC, Ahmed O, Robertson CS (2013) Erythropoietin neuroprotection with traumatic brain injury. Pathophysiology 20: 31-38. [Crossref]

99. Assaraf MI, Diaz Z, Liberman A, Miller WH Jr, Arvanitakis Z, et al. (2007) Brain erythropoietin receptor expression in Alzheimer disease and mild cognitive impairment. J Neuropathol Exp Neurol 66: 389-398. [Crossref]

100. Leuchter RH, Gui L, Poncet A, Hagmann C, Lodygensky GA, et al. (2014) Association between early administration of high-dose erythropoietin in preterm infants and brain MRI abnormality at term-equivalent age. JAMA 312: 817-824. [Crossref]

101. Messier AM, Ohls RK (2014) Neuroprotective effects of erythropoiesis-stimulating agents in term and preterm neonates. Curr Opin Pediatr 26: 139-145. [Crossref]

102. Robertson CS, Hannay HJ, Yamal JM, Gopinath S, Goodman JC, et al. (2014) Effect of erythropoietin and transfusion threshold on neurological recovery after traumatic brain injury: a randomized clinical trial. JAMA 312: 36-47. [Crossref]

103. Nichol A, French C, Little L, Haddad S, Presneill J, et al. (2015) Erythropoietin in traumatic brain injury (EPO-TBI): a double-blind randomised controlled trial. Lancet 386: 2499-2506. [Crossref]

104. Skali H, Parving HH, Parfrey PS, Burdmann EA, Lewis EF, et al. (2011) Stroke in patients with type 2 diabetes mellitus, chronic kidney disease, and anemia treated with Darbepoetin Alfa: the trial to reduce cardiovascular events with Aranesp therapy (TREAT) experience. Circulation 124: 2903-2908. [Crossref]

105. Semeraro F, Cancarini A, Morescalchi F, Romano MR, dell'Omo R, et al. (2014) Serum and intraocular concentrations of erythropoietin and vascular endothelial growth factor in patients with type 2 diabetes and proliferative retinopathy. Diabetes Metab 40: 445-451. [Crossref]
106. De Palo T, Giordano M, Palumbo F, Bellantuono R, Messina G, et al. (2004) Clinical experience with darbepoietin alfa (NESP) in children undergoing hemodialysis. Pediatr Nephrol 19: 337-340. [Crossref]

107. Ogunshola OO, Moransard M, Gassmann M (2013) Constitutive excessive erythrocytosis causes inflammation and increased vascular permeability in aged mouse brain. Brain Res 1531: 48-57. [Crossref]

108. Hedley BD, Allan AL, Xenocostas A (2011) The role of erythropoietin and erythropoiesis-stimulating agents in tumor progression. Clin Cancer Res 17: 63736380. [Crossref]

109. Lombardero M, Kovacs K, Scheithauer BW (2011) Erythropoietin: a hormone with multiple functions. Pathobiology 78: 41-53. [Crossref]

110. Maiese K, Li F, Chong ZZ (2005) Erythropoietin and cancer. JAMA 293:1858-1859. [Crossref]

111. Zhang C, Li Z, Cao Q, Qin C, Cai H, et al. (2014) Association of erythropoietin gene rs576236 polymorphism and risk of adrenal tumors in a Chinese population. $J$ Biomed Res 28: 456-461. [Crossref]

112. Chang ZY, Yeh MK, Chiang CH, Chen YH, Lu DW (2013) Erythropoietin protects adult retinal ganglion cells against NMDA-, trophic factor withdrawal-, and TNF- $\alpha$ induced damage. PLoS One 8: e55291. [Crossref]

113. Chong ZZ, Maiese K (2007) Erythropoietin involves the phosphatidylinositol 3-kinase pathway, 14-3-3 protein and FOXO3a nuclear trafficking to preserve endothelial cell integrity. Br J Pharmacol 150: 839-850. [Crossref]

114. Kwon MS, Kim MH, Kim SH, Park KD, Yoo SH, et al. (2014) Erythropoietin exerts cell protective effect by activating PI3K/Akt and MAPK pathways in C6 Cells. Neurol Res 36: 215-223. [Crossref]

115. Maurice T, Mustafa MH, Desrumaux C, Keller E, Naert G, et al. (2013) Intranasa formulation of erythropoietin (EPO) showed potent protective activity against amyloid toxicity in the Abeta(2)(5)(-)(3)(5) non-transgenic mouse model of Alzheimer's disease. J Psychopharmacol 27: 1044-1057. [Crossref]

116. Wang L, Jia Y, Rogers H, Wu YP, Huang S, et al. (2012) GATA-binding protein 4 (GATA-4) and T-cell acute leukemia (TAL1) regulate myogenic differentiation and erythropoietin response via cross-talk with Sirtuin (Sirt1). J Biol Chem 287: 30157 30169. [Crossref]

117. Wang L, Teng R, Di L, Rogers H, Wu H, et al. (2013) PPARalpha and Sirt1 mediate erythropoietin action in increasing metabolic activity and browning of white adipocytes to protect against obesity and metabolic disorders. Diabetes 62: 4122-4131. [Crossref]

118. Chen X, Wang CC, Song SM, Wei SY, Li JS, et al. (2015) The administration of erythropoietin attenuates kidney injury induced by ischemia/reperfusion with increased activation of Wnt/beta-catenin signaling. J Formos Med Assoc 114: 430437. [Crossref]

119. Danielyan L, Sch Ãafer R, Schulz A, Ladewig T, Lourhmati A, et al (2009) Survival, neuron-like differentiation and functionality of mesenchymal stem cells in neurotoxic environment: the critical role of erythropoietin. Cell Death Differ 16: 1599-1614. [Crossref]

120. Chamorro ME, Wenker SD, Vota DM, Vittori DC, Nesse AB (2013) Signaling pathways of cell proliferation are involved in the differential effect of erythropoietin and its carbamylated derivative. Biochim Biophys Acta 1833: 1960-1968. [Crossref]

Copyright: (C2016 Maiese K. This is an open-access article distributed under the terms of the Creative Commons Attribution License, which permits unrestricted use, distribution, and reproduction in any medium, provided the original author and source are credited. 